\title{
Gambaran Hasil Pemeriksaan Urine pada Pasien dengan Pembesaran Prostat Jinak di RSUP DR. M. Djamil Padang
}

\author{
Azia Putri Al Jamil ${ }^{1}$, Dian Pertiwi², Dwitya Elvira ${ }^{3}$
}

\begin{abstract}
Abstrak
Pembesaran prostat jinak dapat menyebabkan terjadinya hambatan aliran urine, sehingga pasien akan merasakan keluhan pada saluran kemih bagian bawah atau Lower Urinary Tract Symptom (LUTS). Urinalisis merupakan salah satu pemeriksaan yang dapat dilakukan pada pasien dengan LUTS yang terdiri dari pemeriksaan fisik, mikroskopik dan kimia. Tujuan penelitian ini adalah untuk mengetahui gambaran hasil pemeriksaan urine pada pasien dengan pembesaran prostat jinak di RSUP Dr. M. Djamil Padang. Jenis penelitian adalah deskriptif observasional. Sampel diambil menggunakan teknik total sampling di bagian Bedah dan Rekam Medik RSUP. Dr. M. Djamil Padang. Penelitian dilaksanakan dari bulan Januari 2016 sampai Desember 2016 dengan jumlah sampel adalah 40 orang. Data yang digunakan adalah hasil pemeriksaan $\mathrm{pH}$, protein, leukosit, eritrosit dan epitel urine pada rekam medik pasien pembesaran prostat jinak. Data yang sudah dikumpulkan kemudian dianalisis dengan program komputer. Hasil penelitian menunjukkan bahwa 100\% pasien memiliki hasil pH urine 4.5 sampai 8 . Sebanyak $42,5 \%$ memiliki hasil protein urine $1+, 60 \%$ pasien memiliki nilai leukosit $>5 / L P B, 80 \%$ pasien dengan nilai eritrosit $>1 / L P B$ serta $100 \%$ pasien dengan epitel gepeng positif satu (+). Simpulan penelitian ini adalah terdapat peningkatan leukosit, eritrosit dan protein urine pada pasien dengan pembesaran prostat jinak namun $\mathrm{pH}$ dan epitel urine pasien masih dalam nilai normal.
\end{abstract}

Kata kunci: pembesaran prostat jinak, urinalisis,

\section{Abstract}

The enlargement of the prostate will cause urine flow resistance and patient will complain as lower urinary tract symptoms or LUTS. Urinalysis is one of examination of patient with LUTS which consists of physical, microscopic and chemical examination. The objective of this study was to describe the results of urine examination in patients with benign prostatic hyperplasia at RSUP DR M Djamil Padang. This research was descriptive observation. This research used a total sampling technique in surgery ward and medical record of RSUP DR M Djamil Padang. This research began from January to December 2016 which amounts to 40 samples. The data were the results of urinary pH, protein, leukocytes, erythrocytes and epithelial cells on patient medical record. Data was analyzed by computer. The results of this research showed that $100 \%$ patients had urinary pH 4.5 to $8 ., 42.5 \%$ had urinary protein $1+, 60 \%$ patients had leukocytes values $>5 / \mathrm{hpf}$, $80 \%$ patients with erythrocytes values $>1 / \mathrm{hpf}$, and $100 \%$ patients with squamous epithelium $(+)$. The conclusion of this research is the increasing of leukocytes, erythrocytes and urinary protein on patient with benign prostatic hyperplasia, but urinary $\mathrm{pH}$ and epithelial cells still at normal values.

Keywords: benign prostatic hyperplasia, urinalysis

Affiliasi penulis: 1. Prodi Pendidikan Dokter (Fakultas Kedokteran Universitas Andalas Padang (FK Unand), 2. Bagian Patologi Klinik FK unand, 3. Bagian Penyakit Dalam FK Unand/RSUP Dr. M Djamil Padang.

Korespondensi: Azia Putri Al Jamil ,

Email: aziaputrialiamil@gmail.com Telp: 081267045667

\section{PENDAHULUAN}

Benign Prostate Hyperplasia (BPH) atau pembesaran prostat jinak merupakan suatu keadaan terjadinya proliferasi sel stroma prostat yang akan menyebabkan pembesaran dari kelenjar prostat. ${ }^{1}$ 
Pertumbuhan kelenjar prostat terjadi secara konstan selama dua puluh tahun pertama kehidupan lalu berhenti antara usia 20-40 tahun dan mulai kembali pada usia 50 tahun. $^{2}$ Keadaan ini biasanya dialami oleh pria yang berusia diatas 60 tahun sebanyak $70 \%$ dan meningkat hampir $90 \%$ pada usia diatas 80 tahun. $^{3}$

Pembesaran kelenjar prostat akan mengakibatkan terganggunya aliran urine sehingga menimbulkan gangguan miksi. ${ }^{4}$ Pembesaran prostat jinak dapat diketahui melalui pemeriksaan fisik berupa colok dubur atau rectal toucher dan dapat dijadikan pemeriksaan fisik dasar untuk mengetahui informasi mengenai pembesaran prostat jinak. ${ }^{4}$

Penyakit ini merupakan penyebab tersering retensi urine yaitu sekitar $65 \%$ pada laki-laki dewasa. ${ }^{5}$ Retensi urine dapat menjadi faktor risiko untuk terjadinya pertumbuhan bakteri karena adanya stasis aliran urine. ${ }^{6}$ Pembesaran prostat jinak juga menyebabkan masih tersisanya urine didalam kandung kemih karena mengalami dekompensasi sehingga juga meningkatkan risiko pertumbuhan bakteri di saluran kemih dan munculnya kondisi seperti batu saluran kemih. ${ }^{4}$

Penyempitan lumen uretra prostatika akibat pembesaran prostat akan menghambat aliran urine sehingga terjadi peningkatan tekanan intravesikal. Buli-buli harus berkontraksi lebih kuat untuk dapat mengeluarkan urine. Kontraksi yang terus menerus menyebabkan perubahan anatomik buli-buli berupa hipertrofi otot detrusor, trabekulasi, terbentuknya selula, sakula, dan divertikel buli-buli. ${ }^{4}$ Pasien akan merasakannya sebagai keluhan pada saluran kemih bagian bawah atau Lower Urinary Tract Symptom (LUTS). $^{7}$

Pembesaran prostat jinak merupakan penyebab tersering terjadinya LUTS yaitu sekitar $50 \%$ pria yang berusia 60 tahun dan hampir $90 \%$ pria yang berada pada usia 90 akan merasakan gejala dari pembesaran prostat. $^{7}$ Urinalisis adalah pemeriksaan yang paling umum dilakukan dalam praktek urologi yang terdiri dari pemeriksaan fisik, mikroskopik dan kimia. $^{8}$
Urinalisis dapat dilakukan secara manual maupun otomatis dengan melakukan pemeriksaan dipstik ataupun sedimen urine. ${ }^{8}$ Pada pemeriksaan dipstik dan sedimen urine akan didapatkan zat-zat yang terkandung dalam urine seperti eritrosit, leukosit, protein, $\mathrm{pH}$, serta epitel. ${ }^{9,10}$ Pada penelitian Aprilia (2010) didapatkan bahwa 67,86\% pasien pembesaran prostat jinak mengalami leukosituria. ${ }^{10}$

Hematuria merupakan salah satu komplikasi dari pembesaran prostat jinak yang biasanya disebabkan oleh keadaan hipervaskular dari pembesaran prostat yang menyebabkan permukaan pembuluh darah prostat menjadi rapuh dan mudah terganggu oleh aktivitas fisik. ${ }^{12}$ Selain hematuria, kerusakan pada ginjal juga merupakan komplikasi dari pembesaran prostat jinak dan akan dapat ditemukan protein pada urine pasien. ${ }^{13,12}$ Adanya hambatan aliran urine pada pembesaran prostat jinak dapat menyebabkan kondisi infeksi saluran kemih dan akan didapatkan perubahan pada $\mathrm{pH}$ urine. ${ }^{2}$

Berdasarkan penjelasan diatas maka perlu diteliti gambaran hasil pemeriksaan urine pada pasien dengan Pembesaran Prostat Jinak di RSUP Dr. M. Djamil Padang.

\section{METODE}

Penelitian yang dilakukan bersifat deskriptif observasional. Penelitian ini dilakukan di Bagian IImu Bedah dan Instalasi Rekam Medik RSUP DR. M. Djamil Padang mulai bulan Januari 2016 sampai Desember 2016.

Sampel adalah data semua pasien yang didiagnosis pembesaran prostat jinak dengan kelengkapan data mencakup nama pasien, umur pasien dan hasil pemeriksaan urine di bagian bedah di RSUP Dr. M. Djamil Padang yang memenuhi kriteria inklusi dan eksklusi yang berjumlah 40 pasien. Data penelitian yang diperoleh dari hasil rekam medik akan diolah dan dianalisis melalui analisis univariat untuk menghasilkan distribusi dan persentase dari tiap variabel. 
HASIL

Tabel 1. Distribusi frekuensi subjek penelitian berdasarkan Umur

\begin{tabular}{ccc}
\hline Umur (tahun) & Frekuensi & $\%$ \\
\hline$<60$ tahun & 2 & $5 \%$ \\
$60-80$ tahun & 30 & $75 \%$ \\
$>80$ tahun & 8 & $20 \%$ \\
\hline Jumlah & 40 & $100 \%$ \\
\hline
\end{tabular}

Berdasarkan 40 kasus yang diteliti, pasien dengan pembesaran prostat jinak terbanyak ditemukan pada rentang usia 60-80 tahun, yaitu sebanyak 30 pasien $(75 \%)$, sedangkan pada usia $<60$ tahun terdapat sebanyak 2 pasien $(5 \%)$ dan usia $>80$ tahun sebanyak 8 pasien $(2 \%)$.

Tabel 2. Distribusi frekuensi subjek penelitian berdasarkan leukosit urine

\begin{tabular}{ccc}
\hline Leukosit & Frekuensi & $\%$ \\
\hline 0-5/LPB & 16 & $40 \%$ \\
$>5 /$ LPB & 24 & $60 \%$ \\
\hline Jumlah & 40 & $100 \%$
\end{tabular}

Berdasarkan Tabel 2 didapatkan sebagian besar pasien mengalami leukosituria yaitu sebanyak 24 orang $(60 \%)$ memiliki jumlah leukosit urine >5/LPB. Sedangkan pasien dengan jumlah leukosit urine 0 5/LPB terdapat pada 16 orang $(40 \%)$.

Tabel 3. Distribusi frekuensi subjek penelitian berdasarkan jumlah eritrosit urine

\begin{tabular}{ccc}
\hline Eritrosit & Frekuensi & $\%$ \\
\hline $0-1 /$ LPB & 8 & $20 \%$ \\
$>1 /$ LPB & 32 & $80 \%$ \\
\hline Jumlah & 40 & $100 \%$ \\
\hline
\end{tabular}

Berdasarkan Tabel 3 dapat dilihat umumnya pasien mengalami hematuria yaitu sebanyak 32 orang $(80 \%)$ memiliki jumlah eritrosit urine $>1 / L P B$ Sedangkan pasien dengan jumlah eritrosit urine 0 1/LPB terdapat pada 8 orang (20\%).
Tabel 4. Distribusi frekuensi subjek penelitian berdasarkan epitel urine

\begin{tabular}{ccc}
\hline Epitel & Frekuensi & $\%$ \\
\hline$(-)$ & 0 & $0 \%$ \\
$(+)$ & 40 & $100 \%$ \\
$(++)$ & 0 & $0 \%$ \\
$(+++)$ & 0 & $0 \%$ \\
\hline Jumlah & 40 & $100 \%$ \\
\hline
\end{tabular}

Berdasarkan Tabel 4 didapatkan semua pasien pembesaran prostat jinak memiliki hasil pemeriksaan epitel urine gepeng positif satu $(+)(100 \%)$.

Tabel 5. Distribusi frekuensi subjek penelitian berdasarkan derajat keasaman urine

\begin{tabular}{ccc}
\hline $\mathbf{p H}$ & Frekuensi & $\%$ \\
\hline$<4.5$ & 0 & $0 \%$ \\
$4.5-8$ & 40 & $100 \%$ \\
$>8$ & 0 & $0 \%$ \\
\hline Jumlah & 40 & $100 \%$ \\
\hline
\end{tabular}

Berdasarkan Tabel 5 didapatkan 40 pasien $(100 \%)$ memiliki derajat keasaman urine yang berkisar antara 4.5 sampai 8 .

Tabel 6. Distribusi frekuensi subjek penelitian berdasarkan protein urine

\begin{tabular}{ccc}
\hline Protein & Frekuensi & $\%$ \\
\hline$(-)$ & 14 & $35 \%$ \\
+1 & 17 & $42,5 \%$ \\
+2 & 6 & $15 \%$ \\
+3 & 3 & $7,5 \%$ \\
+4 & 0 & $0 \%$ \\
\hline Jumlah & 40 & $100 \%$ \\
\hline
\end{tabular}

Berdasarkan Tabel 6 dapat dilihat dari 40 orang pasien pembesaran prostat jinak, pasien terbanyak dengan protein $1+$ yaitu sebanyak 17 orang (42,5\%). Sedangkan sebanyak 14 orang dengan protein negatif $(-), 6$ orang dengan protein $2+(15 \%), 3$ orang dengan protein $3+(7,5 \%)$ dan tidak ada pasien dengan protein $4+(0 \%)$. 


\section{PEMBAHASAN}

Berdasarkan kelompok umur (Tabel 1) terlihat pasien pembesaran prostat jinak terbanyak berada pada kelompok umur 60 sampai 80 . Jumlah pasien $\mathrm{BPH}$ meningkat sesuai usia. Hal ini sesuai dengan penelitian autopsi bahwa sekitar $8 \%$, 50\% dan $80 \%$ pasien BPH tedapat pada dekade ke 4, 6 dan $9 .^{15}$ Namun terdapat perbedaan pada kelompok umur $>80$ tahun dimana jumlah pasien $\mathrm{BPH}$ paling sedikit dibandingkan kelompok umur lainnya. Hal ini dapat terjadi karena tidak banyak orang yang mencapai usia $>80$ tahun atau kunjungan ke rumah sakit pada kelompok umur tersebut sedikit. ${ }^{11}$

Hasil penelitian didapatkan $60 \%$ pasien memiliki jumlah leukosit >5/LPB dan $40 \%$ pasien yang memiliki jumlah leukosit pada nilai normal yaitu 05/LPB. Hal ini menunjukkan adanya peningkatan leukosit dalam urine pada pasien pembesaran prostat jinak. Keadaan ini sesuai dengan penelitian Aprilia (2010) yang didapatkan bahwa $67,86 \%$ pasien pembesaran prostat jinak mengalami leukosituria. ${ }^{11}$

Leukosituria dapat terjadi karena pada pembesaran prostat jinak akan menyebabkan obtruksi pada kandung kemih dan uretra yang akan menimbulkan retensi urine. Retensi urine sangat berisiko untuk menimbulkan terjadinya infeksi saluran kemih sehingga akan ditemukannya peningkatan leukosit pada urine pasien. ${ }^{15}$ Pada penelitian Fujita et al (2016) juga didapatkan bahwa jumlah leukosit dikaitkan dengan derajat pembesaran prostat dan gejala saluran kemih bagian bawah. ${ }^{16}$

Pada hasil penelitian terhadap eritrosit urine didapatkan $80 \%$ pasien memiliki jumlah eritrosit $>1 /$ LPB dan tidak sesuai dengan nilai normal eritrosit urine yang seharusnya hanya 0-1/LPB. Keberadaan eritrosit per lapangan pandang besar mengindikasikan hematuria mikroskopik yang dapat ditemukan pada beberapa gangguan urologi. $^{8}$ Hematuria atau adanya darah dalam urine merupakan salah satu komplikasi dari pembesaran prostat jinak yang biasanya disebabkan oleh keadaan hipervaskular dari pembesaran prostat yang menyebabkan permukaan pembuluh darah prostat menjadi rapuh dan mudah terganggu oleh aktivitas fisik. ${ }^{12}$

Hematuria dapat dilihat secara langsung pada pemeriksaan makroskopik urine yang biasanya disebut sebagai gross hematuria sedangkan hematuria yang hanya dapat dilihat melalui pemeriksaan mikroskopik urine disebut microscopic hematuria. Keadaan ini dihubungan dengan adanya kerusakan membran glomerular atau adanya trauma vaskular disepanjang traktus urogenital. ${ }^{17}$

Berdasarkan penelitian didapatkan pada hasil pemeriksaan urine seluruh pasien dengan pembesaran prostat jinak memiliki nilai epitel positif satu (+) terutama sel epitel gepeng atau skuamosa. Sel-sel epitel hampir selalu ada pada urine normal dalam jumlah yang kecil. ${ }^{18}$ Sel epitel gepeng pada urine menandakan adanya kontaminasi pada spesimen urine yang berasal dari uretra atau hasil sekresi organ genital. ${ }^{19,20}$

Hasil pemeriksaan protein urine sebagian besar pasien pembesaran prostat jinak memiliki kondisi proteinuria bahkan sebanyak $7.5 \%$ pasien memiliki protein urine $3+$. Proteinuria berat diketahui berhubungan dengan keadaan edema, hipoalbuminemia, hiperlipidemia, tromboemboli dan infeksi. $^{21}$

Pembesaran prostat jinak dapat menimbulkan kerusakan pada ginjal seperti penyakit ginjal kronik yang merupakan salah satu komplikasi BPH. Tekanan intravesikal yang tinggi pada pasien $\mathrm{BPH}$ dapat menimbulkan aliran balik dari buli-buli ke ureter atau terjadi refluks vesiko-ureter. Jika keadaan ini terus berlanjut akan mengakibatkan hidroureter, hidronefrosis bahkan sampai ke gagal ginjal ${ }^{4}$

Pada hasil penelitian terhadap derajat keasaman urine didapatkan semua pasien dengan pembesaran prostat jinak memiliki derajat keasaman urine yang berkisar antara 4.5 sampai 8 . Hasil ini menunjukkan umumnya pasien memiliki $\mathrm{pH}$ urine yang normal. Nilai $\mathrm{pH}$ urine bervariasi dari 4.5 sampai $8 .^{10}$ Pasien yang memiliki $\mathrm{pH}$ urine yang lebih alkali dapat disebabkan karena adanya infeksi yang disebabkan oleh organisme pemecah urea dan kemungkinan adanya gangguan pada ginjal. ${ }^{22}$

\section{SIMPULAN}

Terdapat peningkatan leukosit, eritrosit dan protein urine pada pasien dengan pembesaran prostat jinak namun $\mathrm{pH}$ dan epitel urine pasien masih dalam nilai normal. 


\section{UCAPAN TERIMAKASIH}

Terimakasih kepada Kepala Rekam Medik dan Kepala Bagian Bedah RSUP DR M Djamil Padang sehingga dapat menyelesaikan penelitian ini.

\section{DAFTAR PUSTAKA}

1. Kapoor A. Benign prostatic hyperplasia $(\mathrm{BPH})$ management in the primary care setting. The Canadian Journal of Urology. 2012;10-17.

2. Jiwanggana P. Perbedaan derajat keasaman urin pada penderita pembesaran prostat jinak dengan bakteriuria rendah dan tinggi (skripsi). Fakultas Kedokteran Universitas Sebelas Maret; 2016.

3. Ikatan Ahli Urologi Indonesia. Panduan penatalaksanaan klinis pembesaran prostat jinak (benign prostatic hyperplasia/BPH). 2015.

4. Purnomo BB. Dasar-dasar Urologi Edisi Ke-2. Jakarta: Sagung Seto; 2011.hlm.122-4.

5. Muruganandham K, Dubey D, Kapoor R. Acute urinary retention in benign prostatic hyperplasia: risk factors and current management. Indian Journal of Urology. 2007;23(4):347-53.

6. Marlina, Samad AR. Hubungan pemasangan kateter dengan kejadian infeksi saluran kemih pada pasien di ruang rawat inap penyakit dalam RSUDZA Banda Aceh tahun 2012. Jurnal Keperawatan Medikal Bedah. 2013;1(1):35-47.

7. Barkin J. Benign prostatic hyperplasia and lower urinary tract symptoms: evidence and approaches for best case management. The Canadian Journal of Urology. 2011;18(1):14-9.

8. Musa MU. The role of urine investigations in urology practice. Open Journal of Orthopedics. 2015;5:90-9.

9. Izzah A, Ginardi RH, Saikhu A. Pendekatan algoritma heuristik dan neural network untuk screening test pada urinalysis. Jurnal Cybermatika. 2013;1(2):29-35.

10. Hubbard JD. A concise review of clinical laboratory science. 2nd Edition. Philadelphia: Lippincott Williams \& Wilkins; 2010.hlm.313-23.
11. Aprilia DR. Korelasi antara kejadian leukosituria dan volume prostat penderita pembesaran prostat jinak pada pemeriksaan ultrasonografi (skripsi). Fakultas Kedokteran Universitas Sebelas Maret; 2010.

12. Speakman MJ, Cheng $X$. Management of the complication of bph/boo. India Journal of Urology. 2014;30(2):208-13.

13. Rule $A D$, Lieber MM, Jacobsen SJ. Is benign prostatic hyperplasia a risk factor for chronic renal failure?. The Journal of Urology. 2005; 173 (3): 691-6.

14. Patel ND, Parsons JK. Epidemiology and etiology of benign prostatic hyperplasia and bladder outlet obstruction. Indian Journal of Urology. 2014;30(2): 170-6.

15. Ramdani D, Hasmono D, Islam S. Ciprofloxacin is effective in benign prostatic hyperplasia (BPH) patients with urethral catheters. Folia Medica Indonesiana. 2015;51(2):91-5.

16. Fujita K, Hosomi M, Nagakawa M, Tanigawa G, Imamura R, Uemura M, Nakai $Y$, et al. White blood cell count is positively associated with benign prostatic hyperplasia. International Journal of Urology. 2013;21(3):308-12.

17. Strasinger SK, Lorenzo MSD. Urinalysis and body fluids. 5th Edition. Philadelphia: Davis Company. 200.hlm.57-97.

18. Gandasoebrata R. Penuntun laboratorium klinik. Jakarta: Dian Rakyat. 2010.hlm.116-20.

19. Fogazzi GB, Verdesca S, Garigali G. Urinalysis: core curriculum 2008. American Journal of Kidney Disease. 2008;51(6):1052-67.

20. Simerville JA, Maxted WC, Pahira JJ. Urinalysis: a comprehensive review. American Family Physician. 2005;71(6):1153-62.

21. Venkat KK. Proteinuria and microalbuminuria in adults: significance, evaluation and treatment. Southern Medical Journal. 2004;97(10):969-79.

22. Abirami K, Tiwari SC. Urinalysis in clinical practice (akin to liquid kidney biopsy). Journal Indian Academy of Clinical Medicine. 2001;2(1):39-50. 